\title{
Transforming growth factor activating kinase 1 regulates extracellular matrix degrading enzymes and pain-related molecule expression following tumor necrosis factor-a stimulation of synovial cells: an in vitro study
}

Kentaro Uchida ${ }^{1 *}$, Shotaro Takano ${ }^{1}$, Toshihide Matsumoto ${ }^{2}$, Naoshige Nagura', Gen Inoue ${ }^{1}$, Makoto Itakura ${ }^{3}$, Masayuki Miyagi ${ }^{1}$, Jun Aikawa', Dai Iwase ${ }^{1}$, Atsushi Minatani ${ }^{1}$, Hisako Fujimaki ${ }^{1}$ and Masashi Takaso ${ }^{1}$

\begin{abstract}
Background: Recent studies have suggested that the tumor necrosis factor- $\alpha$ (TNF-a) pathway is a potential target for the management of osteoarthritis (OA). Transforming growth factor (TGF)- $\beta$-activated kinase 1 (TAK1) is essential in several cytokine-mediated cascades, including the TNF- $\alpha$, interleukin-1 (IL-1), and TGF- $\beta$ pathways. The role of TAK1 in synovial tissue in OA is not fully understood. Using synovial cells harvested from OA patients during surgery, we investigated whether TAK1 inhibition suppresses production of TNF-a-induced extracellular matrix degrading enzymes and expression of pain-related molecules.

Methods: Synovial tissues were harvested from ten subjects with radiographic evidence of osteoarthritis (OA) during total knee arthroplasty. Synovial cells were cultured and stimulated with control (culture media), $10 \mathrm{ng} / \mathrm{mL}$ human recombinant TNF-a, or $10 \mathrm{ng} / \mathrm{mL}$ TNF-a and $10 \mu \mathrm{M}$ of the TAK1 inhibitor (5Z)-7-oxozeaenol for $24 \mathrm{~h}$. Real-time polymerase chain reaction (PCR) analysis was used to monitor expression of mRNA of the extracellular matrix degrading enzymes matrix metalloproteinase-3 (MMP-3) and a disintegrin-like and metalloprotease (reprolysin type) with thrombospondin type 1 motif, 4 (ADAMTS-4); and of the pain-related molecules cyclooxygenase-2 (COX-2), microsomal prostaglandin E synthase-1 (mPGES-1), and nerve growth factor (NGF). MMP-3 and NGF protein concentrations in cell supernatant were measured by enzyme-linked immunosorbent assay (ELISA). COX-2, mPGES-1 and ADAMTS-4 protein expression was also evaluated by western blotting.
\end{abstract}

Results: TNF-a stimulated increases in ADAMTS-4 and MMP3 mRNA (2.0-fold and 1.6-fold, respectively, $p<0.05$ ) and protein expression (21.5-fold and 2.0-fold, respectively). Treatment with the TAK1 inihibitor (5Z)-7-oxozeaenol reduced ADAMTS-4 and MMP3 mRNA (0.5-fold and 0.6-fold, respectively) and protein expression (1.4-fold and 0.5-fold, respectively) in OA synovial cells. COX-2, mPGES-1 and NGF mRNA (11.2-fold, 3.1-fold and 2.7-fold, respectively) and protein expression (3.0-fold, 2.7-fold and 2.2-fold, respectively) were increased by TNF-a. (5Z)-7-oxozeaenol treatment reduced mPGES1 and NGF mRNA (1.5-fold and 0.8-fold, respectively) and protein (1.5-fold and 0.5-fold, respectively).

\footnotetext{
*Correspondence: kuchida@med.kitasato-u.ac.jp

'Department of Orthopedic Surgery, Kitasato University School of Medicine,

1-15-1 Minami-ku, Kitasato, Sagamihara City, Kanagawa 252-0374, Japan

Full list of author information is available at the end of the article
} 
(Continued from previous page)

Conclusion: TAK1 plays an important role in the regulation of TNF-a induced extracellular matrix degrading enzymes and pain-related molecule expression. TAK1 may be a potential target for therapeutic strategies aimed at preventing osteoarthritis progression and pain.

Keywords: Synovium, TGF-beta-activated kinase 1, Tumor necrosis factor-alpha, Matrix metalloproteinase 3, A disintegrin-like and metalloprotease (reprolysin type) with thrombospondin type 1 motif, 4, Cyclooxygenase-2, mPGES-1, Nerve growth factor

\section{Background}

Osteoarthritis (OA), the most common joint disease in humans, is characterized by cartilage destruction. Its main symptoms are joint stiffness and pain with associated joint space narrowing. OA severely limits physical activity and greatly impairs quality of life. The identification of molecules that inhibit OA progression and relieve pain is key to OA treatment.

Synovial tissues produce inflammatory cytokines and contribute to OA pathogenesis [1-3]. Several recent studies have suggested that elevation of tumor necrosis factor alpha (TNF- $\alpha$ ) in synovial tissue is linked to OA progression and pain [4-7]. TNF- $\alpha$-induces expression of matrix metalloproteinase-3 (MMP-3) and a disintegrinlike and metalloprotease (reprolysin type) with thrombospondin type 1 motif, ADAMTS-4 (aggrecanase 1) by OA synovial fibroblasts in mice [7]. The anti-TNF antibody infliximab has been shown to slow the progression of OA [5]. TNF- $\alpha$ promotes nerve growth factor (NGF) expression and contributes to peripheral sensitization in $\mathrm{OA}$ mice [6]. In addition, anti-TNF drugs had marked benefits on pain and walking distance, as well as synovitis and joint effusion in a patient with inflammatory knee OA [4]. Synovial fluid levels of TNF- $\alpha$ have been positively correlated with pain score in knee OA [8]. These observations suggest that regulation of the TNF- $\alpha$ pathway in synovial tissues may be key to the management of OA progression and pain.

Transforming growth factor (TGF)- $\beta$-activated kinase 1 (TAK1) is a member of the mitogen-activated protein kinase (MAPK) family [9]. TAK1 is required in the transduction cascades of several cytokine-mediated innate immunity signals, including the TNF- $\alpha$, interleukin1 (IL-1) and TGF- $\beta$ pathways [10-12]. Several studies have suggested that TAK1 is involved in expression of extracellular matrix-degrading enzymes and painrelated molecules [13-18]. Specifically, TAK1 expression has been observed in the synovial tissues of OA and rheumatoid arthritis (RA) patients [14], and TAK1 knockdown in rheumatoid arthritis-affected synoviocytes reduced matrix metalloproteinase-3 (MMP-3) expression by IL-1 $\beta$ [15]. The selective TAK1 inhibitor (5Z)7-oxozeaenol [19] reduced MMP13 and ADAMTS5 in human OA cartilage chondrocytes and synoviocytes without inflammatory cytokine stimulation while blocking degradation of human OA cartilage explants and progression of a rat OA model [18]; TAK1 inhibition reduced TAK1 activation in bovine synovial fibroblasts while increasing reactive oxygen species-induced cyclooxygenase-2 (COX-2) expression [16]; and TAK1 inhibition suppressed nerve growth factor (NGF) expression following TGF- $\beta$ stimulation in cartilage of OA patients [13]. In addition, intra-articular injection of (5Z)-7-oxozeaenol reduced COX-2, MMP-3,-13, and ADAMTS4 expression in injured porcine cartilage [17]. However, the effect of TAK1 on F-F- $\alpha$-induced extracellular matrix-degrading enzymes and pain-related molecules in human osteoarthritic synovial tissues remains undetermined.

We investigated whether TAK1 inhibition suppresses production of TNF- $\alpha$-induced extracellular matrix degrading enzymes and expression of painrelated molecules.

\section{Methods}

\section{Reagents}

Human recombinant TNF- $\alpha$ was purchased from Biolegend (San Diego CA, USA) and (5Z)-7-oxozeaenol was purchased from Sigma (St. Louis, MO, USA).

\section{Patients}

A total of ten participants with radiographic knee OA (unilateral Kellgren/Lawrence $[\mathrm{K} / \mathrm{L}]$ grades $2-4$ ) underwent total knee arthroplasty at our institution. The study included 3 men and 7 women aged 60-89 years (mean \pm SD, $73.8 \pm 8.3$ years) with a mean \pm SD body mass index (BMI) of $26.3 \pm 2.6 \mathrm{~kg} / \mathrm{m}^{2}$ (range 22.6-31.4). A sample of synovial tissue was harvested from the suprapatellar pouch of each operated knee during total knee arthroplasty surgery. Informed consent for participation in this study was obtained from each patient on the day before surgery.

\section{Immunohistochemistry}

To determine the localization of phosphorylated TAK1 (p-TAK1) and TNF- $\alpha$, the paraformaldehyde-fixed synovial tissue samples were embedded in paraffin and sliced into $3-\mu \mathrm{m}$ thick sections. The sections were 
deparaffinized with xylene for $1 \mathrm{~h}$, hydrated in serial dilutions of ethanol (100\%, 95\%, and 70\%) and then rinsed in distilled water. For antigen retrieval, deparaffinized sections were immersed in $10 \mathrm{mM}$ sodium citrate buffer $\mathrm{pH} 6.0$ and maintained at $98{ }^{\circ} \mathrm{C}$ for $30 \mathrm{~min}$. After cooling at room temperature, endogenous peroxidase was blocked with 3\% hydrogen peroxide in methanol for $15 \mathrm{~min}$. The slides were washed in phosphate-buffered saline (PBS) and incubated with 10\% goat serum (Nichirei, Tokyo, Japan) at room temperature. Subsequently, the sections were incubated overnight at $4{ }^{\circ} \mathrm{C}$ with rabbit polyclonal primary antibody against p-TAK1 ( $\mathrm{Thr}^{184} /{ }^{187}$ ) (cat.no. \#4531, Cell Signaling Technology Japan, Tokyo, Japan). After washings twice in PBS, the sections were incubated for $10 \mathrm{~min}$ at room temperature with biotinylated antirabbit IgG (Nichirei). Subsequently, the sections were washed twice in PBS and incubated with horseradish peroxidase (HRP)-conjugated streptavidin for $5 \mathrm{~min}$. Peroxidase activity was revealed by $3,3^{\prime}$-diaminobenzidine (Nichirei) and the sections were counterstained with Mayer's hematoxylin.

\section{Synovial cell culture}

Mononuclear cells were isolated from $500 \mathrm{mg}$ synovium by digestion with $20 \mathrm{~mL}$ of $0.1 \%$ type I collagenase [20]. The cells were cultured ( $\alpha$-minimal essential media $[\mathrm{MEM}]+10 \%$ fetal bovine serum) at $1 \times 10^{4}$ cells $/ \mathrm{cm}^{2}$ in six-well plates. The medium was changed twice over 7 days of culture. Subsequently, the cells were stimulated with control (culture medium), $10 \mathrm{ng} / \mathrm{mL}$ human recombinant TNF- $\alpha$, or $10 \mathrm{ng} / \mathrm{mL}$ TNF- $\alpha$ and $10 \mu \mathrm{M}$ (5Z)-7oxozeaenol for $30 \mathrm{~min}$ or $24 \mathrm{~h}$. The concentration of $10 \mu \mathrm{M}$ (5Z)-7-oxozeaenol was determined based on previous studies [21, 22]. After $30 \mathrm{~min}$, to monitor the efficiency of TAK1 inhibition, phosphorylation of p-38 MAPK was evaluated by western blotting. Subsequently, total protein and mRNA were extracted for real-time PCR and western blotting analysis and the culture supernatant was analyzed for NGF and MMP-3 by enzymelinked immunosorbent assay (ELISA).

\section{Western blotting for $\mathrm{p}-38$ MAPK phosphorylation}

In vitro pharmacology of TAK1 inhibition by (5Z)-7oxozeanol study shows that 3 or $10 \mathrm{uM}$ (5Z)-7-oxozeanol completely inhibits the phosphorylation of p-38 MAPK in the human B cell lymphoma cell line, DOHH-2 [19]. To monitor the efficiency of TAK1 inhibition in synovial cells, phosphorylation of p-38 MAPK was evaluated by western blotting. After $30 \mathrm{~min}$ of treatment, synovial cells were homogenized in sodium dodecyl sulfate (SDS) sample buffer. Proteins of the cellular homogenate ( $5 \mu \mathrm{g} /$ lane) were separated by SDS-polyacrylamide gel electrophoresis and transferred electrophoretically to a polyvinylidene difluoride membrane in blotting buffer.
The filter was blocked with $10 \%$ nonfat milk in $20 \mathrm{mM}$ Tris, $137 \mathrm{mM} \mathrm{NaCl}, 0.1 \%$ Tween 20 [pH 7.6] (TBST) for $30 \mathrm{~min}$ at $20{ }^{\circ} \mathrm{C}$ and then incubated with rabbit polyclonal primary antibodies against phospho-p-38 MAPK $\left(\mathrm{Thr}^{180} / \mathrm{Tyr}^{182}\right.$ ) (cat.no.\#9211; Cell Signaling Technology Japan) or p38-MAPK (cat.no.\#9212; Cell Signaling Technology Japan) for $1 \mathrm{~h}$ at room temperature. The membrane was incubated with peroxidase-labeled goat antirabbit IgG antibody (Zymed Laboratory, San Francisco CA, USA) for $1 \mathrm{~h}$ at room temperature. After washing, the immunoreactive bands were visualized by enhanced chemiluminescence (Super Signal; Pierce, Rockville IL, USA) and a luminescent image analyzer with an electronically cooled charge coupled device (CCD) camera system (LAS-4000mini; Fuji Photo Film Co., Tokyo, Japan).

\section{Real-time PCR analysis}

Total RNA was isolated from the cultured synovial cells using an RNA extract reagent (TRIzol, Invitrogen, Carlsbad CA, USA) following the manufacturer's protocol. The extracted RNA was used as the template for first-strand cDNA synthesis of MMP-3, a disintegrin and metalloproteinase with thrombospondin motifs-4 (ADAMTS-4), COX-2, microsomal prostaglandin E synthase-1(mPGES1), and NGF using Moloney murine leukemia virus (M$\mathrm{MLV}$ ) reverse transcriptase (SuperScript III RT, Invitrogen) in reaction mixtures composed of $2 \mu \mathrm{L}$ cDNA, $0.2 \mu \mathrm{M}$ specific primer pair, $12.5 \mu \mathrm{L} \mathrm{N} \mathrm{N}^{\prime}, \mathrm{N}^{\prime}$-dimethyl-N-[4-[(E)-(3methyl-1,3-benzothiazol-2-ylidene)methyl]-1-phenylquinolin-1-ium-2-yl]-N-propylpropane-1,3-diamine dye reagent (SYBR Premix Ex Taq, Takara, Kyoto, Japan), and nucleasefree water in a final volume of $25 \mu \mathrm{L}$. The primers were designed using Primer Blast open-access software (http:// www.ncbi.nlm.nih.gov/tools/primer-blast/) and were synthesized at Hokkaido System Science Co., Ltd., Sapporo, Japan. The sequences of the PCR primer pairs are listed in Table 1 . The specificity of the amplified products was examined by melt curve analysis. Quantitative PCR was performed using a Real-Time PCR Detection System (CFX-96; Bio-Rad, CA, USA) to determine relative mRNA expression levels. The PCR cycle parameters were as follows: $95{ }^{\circ} \mathrm{C}$ for $1 \mathrm{~min}$, followed by 40 cycles at $95{ }^{\circ} \mathrm{C}$ for $5 \mathrm{~s}$ and at $60{ }^{\circ} \mathrm{C}$ for $30 \mathrm{~s}$. mRNA expression was normalized to the levels of glyceraldehyde-3-phosphate dehydrogenase (GAPDH) mRNA.

\section{Enzyme-linked Immunosorbent assay}

MMP-3 and NGF protein concentrations $/ 100 \mu \mathrm{L}$ of cell culture supernatant were determined using a human MMP-3 ELISA kit (R\&D Systems, Inc., Minneapolis MN, USA) and an NGF ELISA kit (R\&D Systems). 
Table 1 Sequences of the primers used in this study

\begin{tabular}{lll}
\hline Primer & Sequence $\left(5^{\prime}{ }^{\prime} 3^{\prime}\right)$ & Product size (bp) \\
\hline MMP-3-F & GTGGAGTTCCTGACGTGGT & 164 \\
MMP-3-R & TGGAGTCACCTCTTCCCAGA & \\
ADAMTS-4-F & AACACTGAGGACTGCCCAAC & 159 \\
ADAMTS-4-R & GGTGAGTTGCACTGGTCCT & \\
COX-2-F & TGGCTGAGGGAACACAACAG & 74 \\
COX-2-R & AACAACTGCTCATCACCCCA & \\
mPGES-1-F & GGAGACCATCTACCCCTCCT & 81 \\
mPGES-1-R & AAGTGCATCCAGGCGACAAA & \\
NGF-F & CCCATCCCATCTTCCACAGG & 74 \\
NGF-R & GGTGGTCTATCCCCAACCC \\
GAPDH-F & TGTTGCCATCAATGACCCCTT & 202 \\
GAPDH-R & CTCCACGACGTACTCAGCG & \\
\hline
\end{tabular}

\section{Western blotting for ADAMT-4, COX-2, and mPGES1}

To investigate ADAMTS-4, COX-2, and microsomal prostaglandin E2 synthase 1 (mPGES1) protein expression, cells harvested from five patients were stimulated with TNF- $\alpha$, or $10 \mathrm{ng} / \mathrm{mL}$ TNF- $\alpha$ and $10 \mu \mathrm{M}$ (5Z)-7-oxozeaenol, for $24 \mathrm{~h}$. Using methodology described previously [16], synovial cells were then lysed in radioimmune precipitation (RIPA) buffer (Wako Pure Chemical Co., Inc., Osaka, Japan) supplemented with a protease inhibitor cocktail (Roche, Madison WI, USA). The protein concentration for each tissue extract was determined using the bicinchoninic acid (BCA) assay (Pierce, Rockford, Illinois, USA). Protein extracts (10 $\mu \mathrm{g} /$ lane) were separated by sodium dodecyl sulfate-polyacrylamide gel electrophoresis and were electrophoretically transferred onto polyvinyl difluoride membranes, which were then blocked with polyvinylidene fluoride (PVDF) blocking reagent (DS Pharma Biomedical, Suita, Japan) for $1 \mathrm{~h}$. The blocked membranes were incubated overnight at $4{ }^{\circ} \mathrm{C}$ with rabbit polyclonal primary antibodies against ADAMTS-4 (cat. no.ab185722; Abcam), rabbit polyclonal antibodies against COX-2 (cat.no.ab52237; Abcam), or rabbit polyclonal antibodies against mPGES-1 (cat.no.ab62050; Abcam). The primary antibodies were diluted 1:1000 with a blocking reagent (ImmunoBlock, DS Pharma). The membranes were washed with phosphate-buffered saline containing $0.05 \%$ Tween and incubated with the secondary antibodies (GE Healthcare, Piscataway NJ, USA), which had been diluted 1:1000 with blocking reagent. Immunoreactive proteins were visualized by chemiluminescence using an ECL detection system (GE Healthcare) and exposing the membranes to $\mathrm{x}$-ray film. Each band was quantified by densitometric scanning using the NIH software ImageJ. The densitometry readings of the bands were normalized to $\beta$ actin expression.

\section{Statistical analysis}

Differences between the untreated and treated synovial cells were compared using one-way ANOVA with Fisher's least significant difference test. A $p<0.05$ was considered statistically significant. Statistical analyses were performed using commercial software (SPSS v. 19.0, SPSS, Chicago IL, USA).

\section{Results}

\section{Localization of p-TAK1 in osteoarthritic synovium}

To investigate the localization of p-TAK1, immunohistochemical analysis was performed. Immunoreactivity with p-TAK1 was observed in the synovial lining cells of OA patients (Fig. 1).

\section{Inhibition of p38 MAPK phosphorylation by (5Z)-7-oxozeaenol}

Previous studies reported that TAK1 inhibition reduced phosphorylation of p38 MAPK $[18,19]$. We confirmed that TNF- $\alpha$ stimulates p38 MAPK phosphorylation, which is completely inhibited by $10 \mu \mathrm{M}$ (5Z)-7-oxozeaenol (Fig. 2).

\section{Effect of TAK1 inhibition on extracellular matrix degrading enzyme expression}

Real-time PCR analysis revealed that the expression of ADAMTS-4 and MMP-3 increased significantly in synovial cells in the presence of exogenously added TNF- $\alpha$ (2.0-fold and 1.6-fold, respectively, $p<0.05$, Table 2), and their expression was significantly reduced by the TAK 1 inhibitor (5Z)-7-oxozeaenol (0.5-fold and 0.6fold, respectively, $p<0.05$, Table 2 ).

Western blotting analysis revealed that ADAMTS-4 increased in synovial cells in the presence of exogenously added TNF- $\alpha$ (21.5-fold) and that this expression

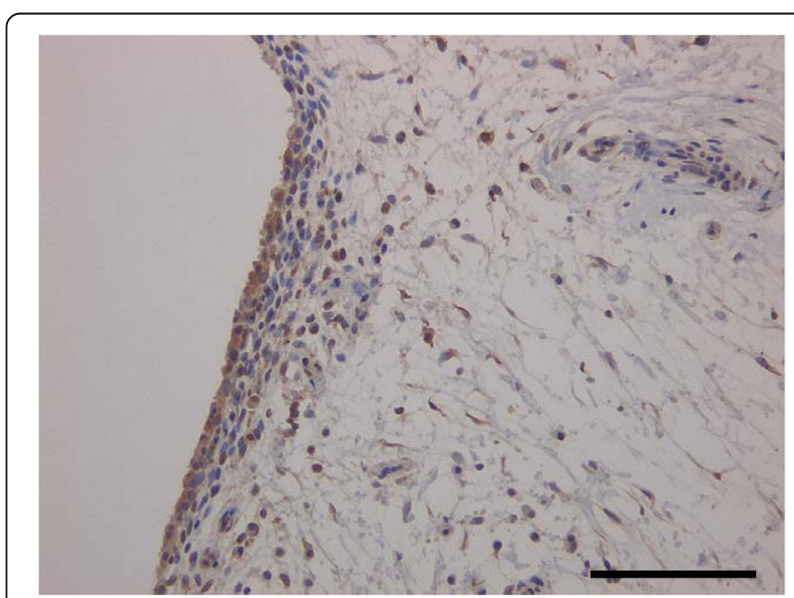

Fig. 1 Immunolocalization of PTAK1 in synovium of OA patients. Immunolocalization of PTAK1. Scale bar $=100 \mu \mathrm{m}$ 


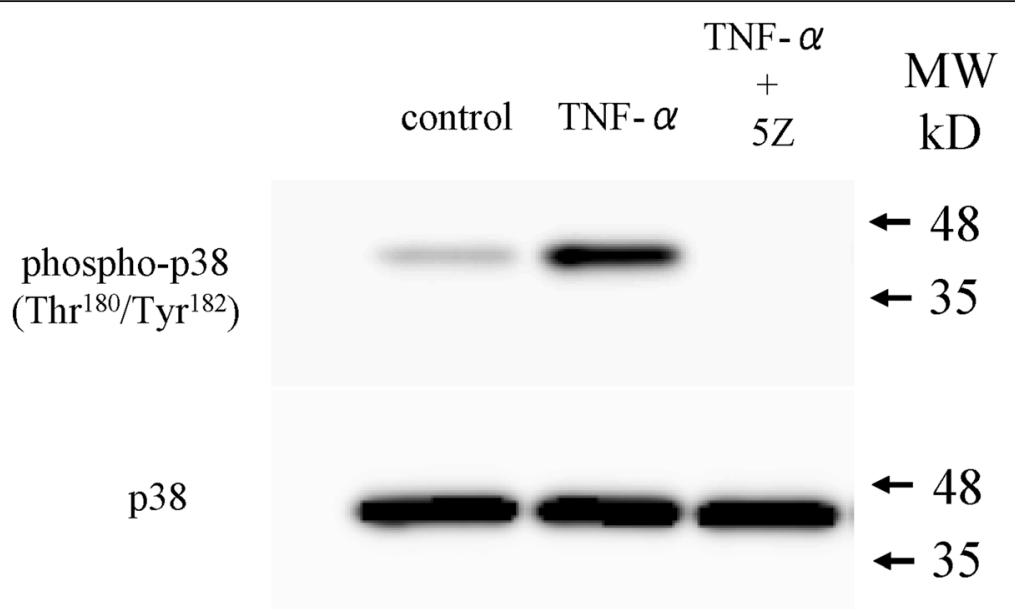

Fig. 2 Effect of TNF-a and TAK1 inhibitor on p38 MAPK phosphorylation. Western blotting analysis for p38 MAPK phosphorylation. Synovial cells were stimulated with human recombinant TNF-a $10 \mathrm{ng} / \mathrm{mL}$ or $10 \mathrm{ng} / \mathrm{mL}$ TNF-a and $10 \mu \mathrm{M}$ (5Z)-7-oxozeaenol (TNF-a + 5Z) for $30 \mathrm{~min}$ prior to protein extraction and analysis of p38 MAPK phosphorylation

was reduced by (5Z)-7-oxozeaenol (Fig. 3 and Table 3, $p<0.05)$. MMP-3 protein levels were also significantly increased in synovial cell culture supernatant in the presence of exogenously added TNF- $\alpha$ (2.0-fold) and this expression was reduced by (5Z)-7-oxozeaenol $(p<0.05$, Table 3).

\section{Effect of TAK1 inhibition on pain-related molecules}

Similarly, COX-2, mPGES1, and NGF mRNA expression increased significantly in synovial cells in the presence of exogenously added TNF- $\alpha$ (11.2-fold, 3.1-fold and 2.7fold, respectively) and were reduced by TNF- $\alpha$ with added (5Z)-7-oxozeaenol (Table 2).

Protein expression of COX-2 and mPGES1 also increased in synovial cells in the presence of exogenously added TNF- $\alpha$ (3.0-fold, 2.7-fold and 2.2-fold, respectively) and $\mathrm{mPGES} 1$ protein expression were significantly reduced by (5Z)-7-oxozeaenol (Fig. 4 and Table 3, $p<0.05$ ).
However, TNF- $\alpha$-induced COX-2 protein elevation was not significantly reduced by (5Z)-7-oxozeaenol $(p=0.065)$. NGF concentration in cell culture supernatant was also significantly increased by TNF- $\alpha$ (2.7-fold; Table $3, p<0.05)$ and decreased by added (5Z)-7-oxozeaenol (Table 3, $p<0.05)$.

\section{Discussion}

This study showed that the phosphorylated TAK1 localized in synovial lining layer of OA patients. TAK1 inhibitor (5Z)-7-oxozeaenol reduced expression of the TNF- $\alpha$-induced extracellular matrix degrading enzymes MMP-3 and ADAMTS-4 and the pain-related molecules mPGES-1 and NGF in the synovial tissues of OA patients.

MMP-3 and ADAMTS-4 have degradative effects on the extracellular matrix, and it has been suggested that they function as important inflammatory mediators in

Table 2 Effect of TNF- $a$ and TAK1 inhibitor on MMP-3, ADAMTS-4, COX-2, mPGES1, and NGF mRNA expression

\begin{tabular}{|c|c|c|c|c|c|c|}
\hline \multirow[t]{2}{*}{ Gene } & \multicolumn{3}{|c|}{ Fold increase } & \multicolumn{3}{|l|}{$p$} \\
\hline & Control & TNF-a & $T N F-a+5 Z$ & Control vs TNF-a & TNF-a vs TNF- $a+5 Z$ & Control vs TNF- $a+5 Z$ \\
\hline ADAMTS-4 & $1.0 \pm 0.1$ & $2.0 \pm 0.1^{a}$ & $0.5 \pm 0.1^{a, b}$ & 0.0003 & $3 \times 10^{-4}$ & 0.031 \\
\hline MMP-3 & $1.0 \pm 0.3$ & $1.6 \pm 0.2^{a}$ & $0.6 \pm 0.1^{b}$ & 0.018 & 0.028 & 0.096 \\
\hline $\operatorname{cox}-2$ & $1.0 \pm 0.3$ & $11.2 \pm 2.6^{a}$ & $4.5 \pm 1.5^{b}$ & 0.007 & 0.014 & 0.065 \\
\hline mPGES1 & $1.0 \pm 0.3$ & $3.1 \pm 0.5^{\mathrm{a}}$ & $1.5 \pm 0.5^{b}$ & 0.024 & 0.003 & 0.483 \\
\hline NGF & $1.0 \pm 0.1$ & $2.7 \pm 0.2^{\mathrm{a}}$ & $0.8 \pm 0.2^{b}$ & 0.006 & 0.003 & 0.312 \\
\hline
\end{tabular}

Real-time polymerase chain reaction analysis for matrix metalloproteinase-3 (MMP-3), a disintegrin-like and metalloprotease (reprolysin type) with thrombospondin type 1 motif, 4 (ADAMTS-4), cycloxygenase-2 (COX-2), microsomal prostaglandin E synthase-1, and nerve growth factor (NGF) gene expression in synovial cell culture. Synovial cells were stimulated with human recombinant $10 \mathrm{ng} / \mathrm{mL}$ TNF- $a$ (TNF- $a$ ), or $10 \mathrm{ng} / \mathrm{ml}$ TNF- $a$ and $10 \mu \mathrm{M}$ (5Z)-7-oxozeaenol (TNF- $a+5 Z$ ) for $24 \mathrm{~h}$ prior to the extraction and analysis of total RNA. All data are presented as the mean \pm standard error $(n=6) .{ }^{a} p<0.05$ compared with the untreated control. ${ }^{\mathrm{b}} p<0.05$ compared with the TNF-a 


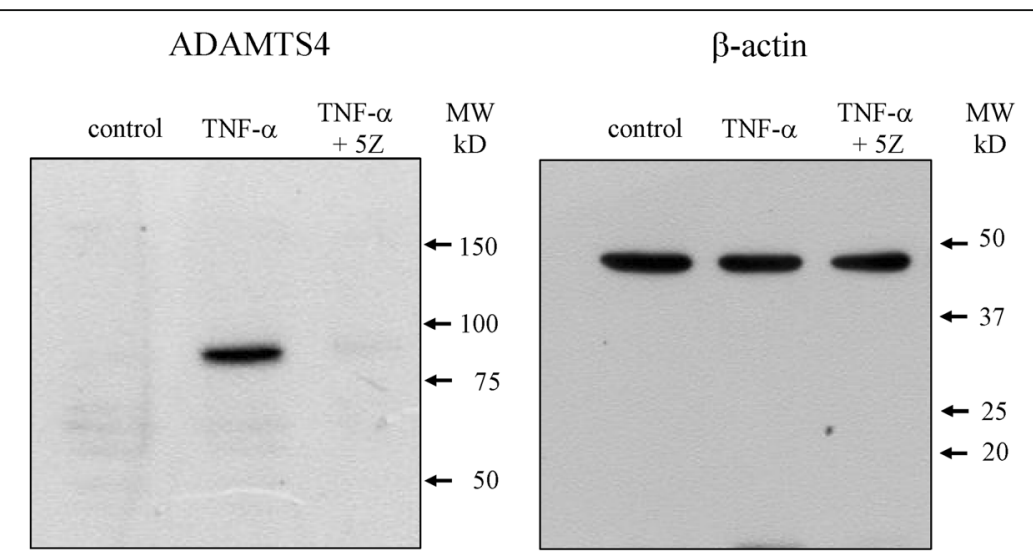

Fig. 3 Effect of TNF-a and TAK1 inhibitor on ADAMTS-4 protein expression. Western blotting analysis for ADAMTS-4. Synovial cells were stimulated with human recombinant TNF-a $10 \mathrm{ng} / \mathrm{mL}$ or $10 \mathrm{ng} / \mathrm{mL}$ TNF-a and $10 \mu \mathrm{M}$ (5Z)-7-oxozeaenol (TNF-a + 5Z) for $24 \mathrm{~h}$ prior to protein extraction and analysis of ADAMTS-4 protein

OA [7, 23-26]. In OA patients, plasma MMP-3 levels correlate closely with joint narrowing [24]. TNF- $\alpha$ stimulates MMP-3 and ADMAMTS-4 in synovial fibroblasts of OA mice [7]. It has been reported that TNF- $\alpha$ neutralization reduces ADAMTS-4 expression in synovial fibroblasts of OA patients [26]. In our study, TNF- $\alpha$-induced MMP-3 and ADAMTS-4 expression was reduced by TAK1 inhibition with (5Z)-7-oxozeaenol in synovial fibroblasts, suggesting that TAK1 contributes to cartilage degradation by the TNF- $\alpha$ elevated MMP-3 and ADAMTS4 in OA synovium.

COX-2 and mPGES-1 enzymes are expressed in synovial lining cells. Prostaglandin E2 (PGE2) levels are elevated in inflamed synovial tissue [20, 27, 28] and TNF- $\alpha$-stimulated synovial cells $[29,30]$. PGE2 is considered to be the major contributor to inflammatory pain in arthritic conditions. Traditionally, non-steroidal anti-inflammatory drugs (NSAIDs), including selective COX-2 inhibitors, have been used to treat pain in OA.
mPGES-1 is upregulated by inflammatory mediators, and gene deletion studies in mice indicate an important role for mPGES1 in inflammatory pain, revealing a different potential target for pain treatment in OA [31, 32]. We found that COX-2 and mPGES1 expression increased with exogenously added TNF- $\alpha$ and decreased with TAK1 inhibition, suggesting that TAK1 may be an important signaling initiator of the PGE2-signaling cascade stimulated by TNF- $\alpha$ in OA synovium.

TNF- $\alpha$-upregulated-COX- 2 and mPGES1 mRNA expression significantly decreased in the presence of (5Z)-7-oxozeaenol consistent with a previous report, where hydrogen peroxide-induced COX-2 elevation suppressed $5 \mu \mathrm{M}$ (5Z)-7-oxozeaenol in bovine synovial fibroblasts. Although COX-2 protein expression was not completely suppressed, phosphorylation of p38 MAPK was reduced below baseline levels. Further investigations into the regulation of COX-2 by TAK1 in synovial cells are needed.

Table 3 Effect of TNF- $a$ and TAK1 inhibitor on MMP-3, ADAMTS-4, COX-2, mPGES1, and NGF protein expression

\begin{tabular}{|c|c|c|c|c|c|c|}
\hline \multirow[t]{2}{*}{ Protein } & \multicolumn{3}{|c|}{ Fold increase } & \multicolumn{3}{|l|}{$p$} \\
\hline & Control & TNF-a & TNF- $a+5 Z$ & Control vs TNF-a & TNF- $a$ vs TNF- $a+5 Z$ & Control vs TNF- $a+5 Z$ \\
\hline ADAMTS-4 & $1.0 \pm 0.2$ & $21.5 \pm 2.8^{a}$ & $1.4 \pm 0.3^{b}$ & 0.015 & 0.015 & 0.103 \\
\hline MMP-3 & $1.0 \pm 0.2$ & $2.0 \pm 0.1^{\mathrm{a}}$ & $0.5 \pm 0.1^{\mathrm{a}, \mathrm{b}}$ & 0.001 & $1 \times 10^{-6}$ & 0.015 \\
\hline $\operatorname{cox}-2$ & $1.0 \pm 0.3$ & $3.0 \pm 0.1^{\mathrm{a}}$ & $2.2 \pm 0.1^{\mathrm{a}}$ & 0.001 & 0.052 & 0.022 \\
\hline mPGES1 & $1.0 \pm 0.1$ & $2.7 \pm 0.1^{a}$ & $1.5 \pm 0.1^{a, b}$ & 0.004 & 0.006 & 0.027 \\
\hline NGF & $1.0 \pm 0.2$ & $2.2 \pm 0.6^{\mathrm{a}}$ & $0.5 \pm 0.1^{a, b}$ & 0.032 & 0.017 & 0.009 \\
\hline
\end{tabular}

Protein analysis for matrix metalloproteinase-3 (MMP-3), a disintegrin-like and metalloprotease (reprolysin type) with thrombospondin type 1 motif, 4 (ADAMTS-4), cycloxygenase-2 (COX-2), microsomal prostaglandin E synthase-1, and nerve growth factor (NGF) gene expression in synovial cell culture. Synovial cells were stimulated with human recombinant $10 \mathrm{ng} / \mathrm{mL}$ TNF-a (TNF-a), or $10 \mathrm{ng} / \mathrm{ml}$ TNF-a and $10 \mu \mathrm{M}$ (5Z)-7-oxozeaenol (TNF-a $+5 \mathrm{Z}$ ) for $24 \mathrm{~h}$ prior to the protein extraction. Expression of ADAMTS-4, COX-2, and mPGES1 proteins were analyzed by western blotting analysis. MMP3 and NGF protein levels in synovial cell culture supernatants were measured by ELISA. All data are presented as the mean \pm standard error $(n=6)$. ${ }^{a} p<0.05$ compared with the untreated control. ${ }^{\mathrm{b}} p<0.05$ compared with the TNF-a 


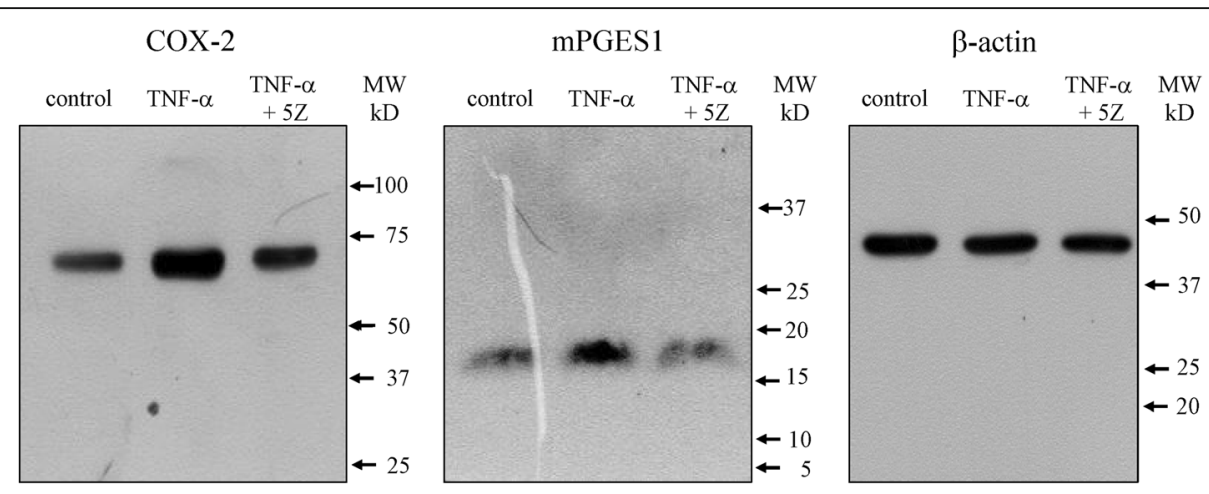

Fig. 4 Effect of TNF-a and TAK1 inhibitor on COX-2 and mPGES1 protein expression. Western blotting analysis for COX-2 and mPGES1. Synovial cells were stimulated with human recombinant TNF-a $10 \mathrm{ng} / \mathrm{mL}$ or $10 \mathrm{ng} / \mathrm{mL}$ TNF-a and $10 \mu \mathrm{M}$ (5Z)-7-oxozeaenol (TNF-a + 5Z) for 24 h prior to protein extraction and analysis of COX-2 and MPGES1 protein

NGF also plays an important role in OA pain [6,33-36], and the neutralization of NGF with tanezumab, an antiNGF monoclonal antibody, has robust analgesic effects $[33,35,36]$. TNF- $\alpha$ stimulates NGF expression in OA synovial fibroblasts in vivo and in vitro [6,37]. NGF and COX-2 expression have been considered to be regulated by inflammatory cytokines; however, several studies have reported that NGF and COX-2 are regulated by different pathways [38, 39]. COX-2 inhibitors have limited effect on IL1B-induced NGF expression in human synovial fibroblasts [38], but increase IL1B-induced NGF expression in human intervertebral disc cells [39]. Yazici et al. reported that combination therapy with tanezumab and NSAIDs was associated with greater improvement in knee and hip OA pain than NSAIDs alone [40]. In our study, TAK1 inhibition reduced not only mPGES1 expression but also NGF expression, suggesting that TAK1 may be therapeutic target for OA pain.

Several limitations of the present study warrant mention. First, we evaluated a single concentration of TNF- $\alpha$ at one time point. Second, this was an in vitro study. It remains to be determined if TAK1 inhibition will reduce OA progression and pain in vivo. Finally, we showed that TAK1 inhibition reduced MMP-3 and ADAMTS-4 levels, however, it remains to be determined whether blockage of TAK1 inhibits degradation of ECM proteins. This may be elucidated by investigating whether cell supernatants degrade purified extracellular matrix using an overlay assay [41].

\section{Conclusions}

In conclusion, TAK1 upregulates TNF- $\alpha$-induced extracellular matrix-degrading enzymes and pain-related molecule expression in OA synovial tissues. These properties suggest that TAK1 in synovial tissue may be a potential target for therapeutic strategies for osteoarthritic progression and pain.

\section{Abbreviations}

ADAMTS-4: A disintegrin-like and metalloprotease (reprolysin type) with thrombospondin type 1 motif, 4; BCA: Bicinchoninic acid; COX2: Cyclooxygenase-2; ELISA: Enzyme-linked immunosorbent assay; GAPDH: Glyceraldehyde-3-phosphate dehydrogenase; IL-1: Interleukin-1; IL13: Interleukin-1 3 ; MAPK: Mitogen-activated protein kinase; MMP-3: Matrix metalloproteinase-3; mPGES-1: Microsomal prostaglandin E synthase-1; NGF: Nerve growth factor; NSAIDs: Nonsteroidal anti-inflammatory drugs; OA: Osteoarthritis; PCR: Polymerase chain reaction; PGE2: Prostaglandin E2; PVDF: Polyvinylidene fluoride; RIPA: Radioimmune precipitation; SYBR: N',N '-dimethyl-N-[4-[(E)-(3-methyl-1,3-benzothiazol-2-ylidene)methyl]-1phenylquinolin-1-ium-2-yl]-N-propylpropane-1,3-diamine; TAK1: Transforming growth factor (TGF)- $\beta$-activated kinase; TNFa: Tumor necrosis factor-a; $\alpha$ MEM: a-minimal essential media

\section{Acknowledgements}

We thank Ms. Yuko Onuki for her assistance in the real time PCR analysis of the data in this study.

\section{Funding}

This investigation was supported in part by JSPS KAKENHI Grant no. 15K20016, the Uehara Memorial Foundation; a Kitasato University Research Grant for Young Researchers; and research grants from the Parents' Association of Kitasato University School of Medicine.

\section{Availability of data and materials}

The raw data can be requested from the corresponding author.

\section{Authors' contributions}

$\mathrm{KU}, \mathrm{Gl}$ and $\mathrm{MT}$ designed the study and performed the analysis of the data. $\mathrm{KU}$ wrote the manuscript. ST, TM, NN, MI, AM, Jl, MM, DI, and HF participated in the data collection. All authors read and approved the final manuscript.

\section{Ethics approval and consent to participate}

This study was approved by the Ethics Review Board of Kitasato University (reference number: KMEO B13-113). Consent to participate was obtained from the participants for the harvesting of their synovial tissue for use in this study.

\section{Consent for publication}

Not applicable.

\section{Competing interests}

The authors declare that they have no competing interests.

\section{Publisher's Note}

Springer Nature remains neutral with regard to jurisdictional claims in published maps and institutional affiliations. 


\section{Author details}

Department of Orthopedic Surgery, Kitasato University School of Medicine, 1-15-1 Minami-ku, Kitasato, Sagamihara City, Kanagawa 252-0374, Japan. ${ }^{2}$ Department of Pathology, Kitasato University School of Medicine, 1-15-1 Minami-ku, Kitasato, Sagamihara City, Kanagawa 252-0374, Japan. ${ }^{3}$ Department of Biochemistry, Kitasato University School of Medicine, 1-15-1 Minami-ku, Kitasato, Sagamihara City, Kanagawa 252-0374, Japan.

Received: 15 January 2017 Accepted: 27 June 2017

Published online: 01 July 2017

\section{References}

1. Benito MJ, Veale DJ, FitzGerald O, van den Berg WB, Bresnihan B. Synovial tissue inflammation in early and late osteoarthritis. Ann Rheum Dis. 2005; 64(9):1263-7.

2. Farahat MN, Yanni G, Poston R, Panayi GS. Cytokine expression in synovial membranes of patients with rheumatoid arthritis and osteoarthritis. Ann. Rheum.Dis. 1993;52(12):870-5

3. Young L, Katrib A, Cuello C, Vollmer-Conna U, Bertouch JV, RobertsThomson PJ, Ahern MJ, Smith MD, Youssef PP. Effects of intraarticular glucocorticoids on macrophage infiltration and mediators of joint damage in osteoarthritis synovial membranes: findings in a double-blind, placebocontrolled study. Arthritis Rheum. 2001;44(2):343-50.

4. Grunke M, Schulze-Koops $H$. Successful treatment of inflammatory knee osteoarthritis with tumour necrosis factor blockade. AnnRheumDis. 2006; 65(4):555-6.

5. Guler-Yuksel M, Allaart CF, Watt I, Goekoop-Ruiterman YP, de Vries-Bouwstra JK, Van SD, van Krugten MV, Dijkmans BA, Huizinga TW, Lems WF, Kloppenburg M. Treatment with TNF-alpha inhibitor infliximab might reduce hand osteoarthritis in patients with rheumatoid arthritis. Osteoarthritis.Cartilage. 2010;18(10):1256-62.

6. Takano S, Uchida K, Miyagi M, Inoue G, Fujimaki H, Aikawa J, Iwase D, Minatani A, Iwabuchi K, Takaso M. Nerve growth factor regulation by TNFalpha and IL-1beta in synovial macrophages and fibroblasts in Osteoarthritic mice. J ImmunolRes. 2016;2016:5706359.

7. Uchida K, Satoh M, Inoue G, Onuma K, Miyagi M, Iwabuchi K, Takaso M. CD11C(+) macrophages and levels of TNF-alpha and MMP-3 are increased in synovial and adipose tissues of osteoarthritic mice with hyperlipidaemia. ClinExplmmunol. 2015;180(3):551-9.

8. Orita S, Koshi T, Mitsuka T, Miyagi M, Inoue G, Arai G, Ishikawa T, Hanaoka E, Yamashita K, Yamashita M, Eguchi Y, Toyone T, Takahashi K, Ohtori S. Associations between proinflammatory cytokines in the synovial fluid and radiographic grading and pain-related scores in 47 consecutive patients with osteoarthritis of the knee. BMC Musculoskelet Disord. 2011:12:144.

9. Yamaguchi K, Shirakabe K, Shibuya H, Irie K, Oishi I, Ueno N, Taniguchi T, Nishida E, Matsumoto K. Identification of a member of the MAPKKK family as a potential mediator of TGF-beta signal transduction. Science. 1995; 270(5244):2008-11.

10. Hasegawa M, Fujimoto $Y$, Lucas PC, Nakano H, Fukase $K$, Nunez G, Inohara N. A critical role of RICK/RIP2 polyubiquitination in nod-induced NF-kappaB activation. EMBO J. 2008;27(2):373-83

11. Ninomiya-Tsuji J, Kishimoto K, Hiyama A, Inoue J, Cao Z, Matsumoto K. The kinase TAK1 can activate the NIK-I kappaB as well as the MAP kinase cascade in the IL-1 signalling pathway. Nature. 1999;398(6724):252-6.

12. Shibuya H, Yamaguchi K, Shirakabe K, Tonegawa A, Gotoh Y, Ueno N, Irie K, Nishida E, Matsumoto K. TAB1: an activator of the TAK1 MAPKKK in TGFbeta signal transduction. Science. 1996;272(5265):1179-82.

13. Blaney Davidson EN, van Caam AP, Vitters EL, Bennink MB, Thijssen E, van den Berg WB, Koenders MI, van Lent PL, van de Loo FA, van der Kraan PM. TGF-beta is a potent inducer of nerve growth factor in articular cartilage via the ALK5-Smad2/3 pathway. Potential role in OA related pain? Osteoarthritis. Cartilage. 2015;23(3):478-86.

14. Hammaker DR, Boyle DL, Chabaud-Riou M, Firestein GS. Regulation of c-Jun $\mathrm{N}$-terminal kinase by MEKK-2 and mitogen-activated protein kinase kinase kinases in rheumatoid arthritis. J Immunol. 2004;172(3):1612-8.

15. Hammaker DR, Boyle DL, Inoue T, Firestein GS. Regulation of the JNK pathway by TGF-beta activated kinase 1 in rheumatoid arthritis synoviocytes. Arthritis Res Ther. 2007;9(3):R57.

16. Onodera Y, Teramura T, Takehara T, Shigi K, Fukuda K. Reactive oxygen species induce Cox-2 expression via TAK1 activation in synovial fibroblast cells. FEBS OpenBio. 2015;5:492-501.
17. Ismail HM, Didangelos A, Vincent TL, Saklatvala J. Rapid activation of transforming growth factor beta-activated Kinase 1 in Chondrocytes by Phosphorylation and K63-linked Polyubiquitination upon injury to animal Articular cartilage. Arthritis Rheumatol. 2017;69(3):565-75.

18. Cheng J, Hu X, Dai L, Zhang X, Ren B, Shi W, Liu Z, Duan X, Zhang J, Fu X, Chen W, Ao Y. Inhibition of transforming growth factor beta-activated kinase 1 prevents inflammation-related cartilage degradation in osteoarthritis. SciRep. 2016;6:34497.

19. Wu J, Powell F, Larsen NA, Lai Z, Byth KF, Read J, Gu RF, Roth M, Toader D, Saeh JC, Chen $\mathrm{H}$. Mechanism and in vitro pharmacology of TAK1 inhibition by (5Z)-7-Oxozeaenol. ACS ChemBiol. 2013;8(3):643-50.

20. Minatani A, Uchida K, Inoue G, Takano S, Aikawa J, Miyagi M, Fujimaki H, Iwase D, Onuma K, Matsumoto T, Takaso M. Activation of calcitonin generelated peptide signaling through the prostaglandin E2-EP1/EP2/EP4 receptor pathway in synovium of knee osteoarthritis patients. J Orthop SurgRes. 2016;11(1):117.

21. Jung SM, Lee JH, Park J, Oh YS, Lee SK, Park JS, Lee YS, Kim JH, Lee JY, Bae YS, Koo SH, Kim SJ, Park SH. Smad6 inhibits non-canonical TGF-beta1 signalling by recruiting the deubiquitinase A20 to TRAF6. NatCommun. 2013:4:2562.

22. Lane J, Yumoto K, Azhar M, Ninomiya-Tsuji J, Inagaki M, Hu Y, Deng CX, Kim J, Mishina Y, Kaartinen V. Tak1, Smad4 and Trim33 redundantly mediate TGFbeta3 signaling during palate development. DevBiol. 2015;398(2):231-41.

23. Verma P, Dalal K. ADAMTS-4 and ADAMTS-5: key enzymes in osteoarthritis. J Cell Biochem. 2011;112(12):3507-14

24. Lohmander LS, Brandt KD, Mazzuca SA, Katz BP, Larsson S, Struglics A, Lane KA. Use of the plasma stromelysin (matrix metalloproteinase 3) concentration to predict joint space narrowing in knee osteoarthritis. Arthritis Rheum. 2005;52(10):3160-7

25. Pelletier JP, McCollum R, Cloutier JM, Martel-Pelletier J. Synthesis of metalloproteases and interleukin 6 (IL-6) in human osteoarthritic synovial membrane is an IL-1 mediated process. J RheumatolSuppl. 1995:43:109-14.

26. Bondeson J, Wainwright SD, Lauder S, Amos N, Hughes CE. The role of synovial macrophages and macrophage-produced cytokines in driving aggrecanases, matrix metalloproteinases, and other destructive and inflammatory responses in osteoarthritis. Arthritis Res Ther. 2006;8(6):R187.

27. Kojima F, Naraba H, Sasaki Y, Beppu M, Aoki H, Kawai S. Prostaglandin E2 is an enhancer of interleukin-1 beta-induced expression of membraneassociated prostaglandin E synthase in rheumatoid synovial fibroblasts. Arthritis Rheum. 2003;48(10):2819-28.

28. Kojima F, Naraba H, Sasaki Y, Okamoto R, Koshino T, Kawai S. Coexpression of microsomal prostaglandin E synthase with cyclooxygenase-2 in human rheumatoid synovial cells. J Rheumatol. 2002;29(9):1836-42.

29. Stichtenoth DO, Thoren S, Bian H, Peters-Golden M, Jakobsson PJ, Crofford LJ Microsomal prostaglandin $\mathrm{E}$ synthase is regulated by proinflammatory cytokines and glucocorticoids in primary rheumatoid synovial cells. J Immunol. 2001:167(1):469-74.

30. Ke J, Long X, Liu Y, Zhang YF, Li J, Fang W, Meng QG. Role of NF-kappaB in TNF-alpha-induced COX-2 expression in synovial fibroblasts from human TMJ. J DentRes. 2007:86(4):363-7.

31. Dray A, Read SJ. Arthritis and pain. Future targets to control osteoarthritis pain. Arthritis Res Ther. 2007;9(3):212.

32. Trebino CE, Stock UL, Gibbons CP, Naiman BM, Wachtmann TS, Umland JP, Pandher K, Lapointe JM, Saha S, Roach ML, Carter D, Thomas NA, Durtschi BA, McNeish JD, Hambor JE, Jakobsson PJ, Carty TJ, Perez JR, Audoly LP. Impaired inflammatory and pain responses in mice lacking an inducible prostaglandin E synthase. ProcNat|AcadSciUSA. 2003;100(15):9044-9.

33. Brown MT, Murphy FT, Radin DM, Davignon I, Smith MD, West CR. Tanezumab reduces osteoarthritic knee pain: results of a randomized, double-blind, placebo-controlled phase III trial. J Pain. 2012;13(8):790-8.

34. Seidel MF, Wise BL, Lane NE. Nerve growth factor: an update on the science and therapy. OsteoarthritisCartilage. 2013;21(9):1223-8.

35. Lane NE, Schnitzer TJ, Birbara CA, Mokhtarani M, Shelton DL, Smith MD, Brown MT. Tanezumab for the treatment of pain from osteoarthritis of the knee. NEnglJ Med. 2010;363(16):1521-31.

36. Sanga P, Katz N, Polverejan E, Wang S, Kelly KM, Haeussler J, Thipphawong J. Efficacy, safety, and tolerability of fulranumab, an anti-nerve growth factor antibody, in the treatment of patients with moderate to severe osteoarthritis pain. Pain. 2013;154(10):1910-9.

37. Manni L, Aloe L. Role of IL-1 beta and TNF-alpha in the regulation of NGF in experimentally induced arthritis in mice. Rheumatollnt. 1998;18(3):97-102. 
38. Yorifuji M, Sawaji Y, Endo K, Kosaka T, Yamamoto K. Limited efficacy of COX2 inhibitors on nerve growth factor and metalloproteinases expressions in human synovial fibroblasts. J Orthop Sci. 2016;21(3):381-8.

39. Alimasi W, Sawaji Y, Endo K, Yorifuji M, Suzuki H, Kosaka T, Shishido T, Yamamoto K. Regulation of nerve growth factor by anti-inflammatory drugs, a steroid, and a selective cyclooxygenase 2 inhibitor in human intervertebral disc cells stimulated with interleukin-1. Spine (Phila Pa 1976.) 2013; 38 (17): 1466-1472.

40. Yazici Y, Ekman EF, Greenberg HS, Smith MD, Brown MT, West CR, Verburg KM. Efficacy of Tanezumab compared with non-steroidal anti-inflammatory drugs in patients with knee or hip osteoarthritis (NCT00809354). Arthritis Rheum. 2011;63(Supple 10):S326. (GENERIC)

41. Ismail HM, Yamamoto K, Vincent TL, Nagase H, Troeberg L, Saklatvala J. Interleukin-1 acts via the JNK-2 signaling pathway to induce Aggrecan degradation by human Chondrocytes. Arthritis Rheumatol. 2015;67(7):1826-36.

Submit your next manuscript to BioMed Central and we will help you at every step:

- We accept pre-submission inquiries

- Our selector tool helps you to find the most relevant journal

- We provide round the clock customer support

- Convenient online submission

- Thorough peer review

- Inclusion in PubMed and all major indexing services

- Maximum visibility for your research

Submit your manuscript at www.biomedcentral.com/submit
Biomed Central 